\title{
THERMODYNAMIC EVALUATION OF A TWO STAGES COMPRESSION REFRIGERATION SYSTEM INTEGRATED TO AN ABSORPTION SYSTEM
}

\author{
G. A. Corrêa ${ }^{a}$, \\ J.A. Souza ${ }^{a}$, \\ C. Prentice-Hernández ${ }^{b}$, \\ and L. A. O. Rocha ${ }^{\mathrm{a}, *}$ \\ ${ }^{\mathrm{a}}$ FURG - Universidade Federal do Rio Grande \\ Escola de Engenharia, Av. Itália, km 8, \\ 96201-900 Campus Carreiros, Rio Grande, \\ RS, Brasil \\ laorocha@gmail.com \\ ${ }^{\mathrm{b}}$ FURG - Universidade Federal do Rio Grande \\ Escola de Química e Alimentos, \\ Rua Eng. Alfredo Huch, 475 96201-900, \\ Campus Cidade, Rio Grande, RS Brasil
}

ABSTRACT

This work is based on the principles of administration, with technical and economic data from a frigorific fishing industry, at analyzing the convenience of integrating to the existing refrigeration system (by vapor compression) a refrigeration system by absorption. By comparing the existing system, and this one integrated with absorption, it was applied a thermodynamic evaluation for a mean frigorific output of $33.43 \mathrm{~kW}$. The profitable result obtained from this evaluation indicated the feasibility of the integrated refrigeration system, with an operation time of up to $25.64 \%$, less than the existing refrigeration system, enabling a lower amount of time for investment return than five years. In the evaluation, they were compared the energetic model, associating energy and the operation cost. The highest profitability of integrated system shows, for the system applied in the industry, that by applying such system it contributes to lower the operations costs, with further results of increased in the product offer, and competitiveness in marketing frigorific items.

Keywords: refrigeration, compression-absorption, thermoeconomy

\section{NOMENCLATURE}

A1 Annual operating cost of the CRS

A2 Annual operating cost of the IRS

ARS Absorption refrigeration system

C Cost

COP Coefficient of performance

CRS Compression refrigeration system

CRSmod CRS modified system

E Exergy $\left(\mathrm{kJ} . \mathrm{s}^{-1}\right)$

$\mathrm{F} \quad$ Value of the equipment depreciated for $\mathrm{n}$ years (residual)

g Updating factor of value in a simple payment

EV Expansion valve

$\mathrm{H} \quad$ Number of hours per year [h]

IRS Integrated refrigeration system

i Annual interest rate [\%]

I Investment

$\dot{\mathrm{m}} \quad$ Flow mass $[\mathrm{kg} / \mathrm{s}]$

L Labor

n' Return period

n Number of years

$\mathrm{P} \quad$ Present value

$\mathrm{t} \quad$ Factor of annual maintenance [\%]

VPL Presented liquid value

$\dot{\mathrm{W}} \quad$ Power $[\mathrm{kJ} / \mathrm{s}]$

$\Delta \mathrm{h} \quad$ Integrated refrigeration system

\section{Subscripts}

$\begin{array}{ll}\text { ARS } & \text { Absorption refrigeration system } \\ \text { CRS } & \text { Compression refrigeration system } \\ \text { b } & \text { Water vapor } \\ \text { e } & \text { Electric } \\ \text { el } & \text { Electricity } \\ \text { f } & \text { Cold production } \\ \text { G } & \text { Generator } \\ \text { i } & \text { Maintenance of the investment } \\ \text { q } & \text { Heat }\end{array}$

\section{INTRODUCTION}

The use of combined systems of absorption and compression in industrial refrigerating, using the thermal waste, has gained more and more followers, changing, thus, the energetic consumption profile in the frigorific sector. Such hybrid systems have a series of economic, social and environmental advantages benefits, hence, a highly important criterion for a proposal of using such wastes, is the selection of companies which have an amount of heat not used in the process. The most appropriate technology for analyzing such combined cycles is the thermoeconomy, which studies energetic systems in need of technical and economic viability. 
The economic model applied in this work was based on the study of a number of researchers. Hirschfeld, 1984, studies techniques for developing valuing criteria, system engineering, modern adequation of benefit-cost relationship and dominating financial mathematics. He also studies practical examinations, as replacement of equipment and inflation, as well as explaining in detail depreciation methods. Bejan et al., 1996, focused on applying the principles of exergy and its application in the analysis of thermical and thermoeconomic systems. They showed, still, how variables related to exergy, can be used for minimizing the cost of a thermical system, for example, the exergetic efficiency, invested capital, operation and maintenance of thermal systems. Erlach et al., 1999, by connecting thermodynamics to economy, take into account thermoeconomy as a new science; moreover, they developed tools to solve complex energetic problems, which would hardly be solved using the conventional energetic analysis based on the First Law of Thermodynamics. Among the problems solved, for example, there is the rational attribution of cost to products of an energetic plant or the operational optimization of a system. Souza et al, 2004, presented a technical and economic analysis of a pilot refrigerating unit made up of a compression system and a water/ammonia absorption system which uses natural gas as energy source. They presented cash flow sheets with expenditures and incomes, set to determine economic net indicators and profitability, the present liquid value (VPL), the return tax and the estimated time of payback investment. Pellegrini et al., 2005, showed thermoeconomy as a method of attributing costs to an energetic system. They were based on the assumption that exergy is the only rational way of assigning cost to flow (products) of an energetic system. Misra et al., 2006, applied the concept of thermodynamics in optimizing the refrigeration systems water/ammonia, aiming at minimizing production costs. Yet, they presented a methodology for obtaining thermodynamic properties such as chemical exergy of mixture water/ammonia.

This work aims to evaluate the thermo economic convenience of integrating to the existing refrigeration system, by vapor compression of an industry, a refrigeration system by absorption.

\section{Integrated Refrigeration System (IRS)}

The measure taken, when the difference was very high between the temperatures of hot and cold sources of the refrigerating cycle, is the compression by stages. It enables, through intermediary refrigeration, to reduce the work of compression and results in an increase of frigorific performance in the installation. (ASHRAE, 1994). Such procedure usually takes place by injecting liquid between the stages, where part of the refrigerating fluid, which could be applied to increase frigorific capacity, is used in deoverheating the mass flow discharged by the compressor in the first stage. (Stoecker, 1998).

The alternative for this intermediary refrigeration, shown in Fig.1, is applying cold water in a closed circuit using a absorption ammonia-water refrigeration system integrated with the compression one, called Integrate Refrigeration System (IRS).

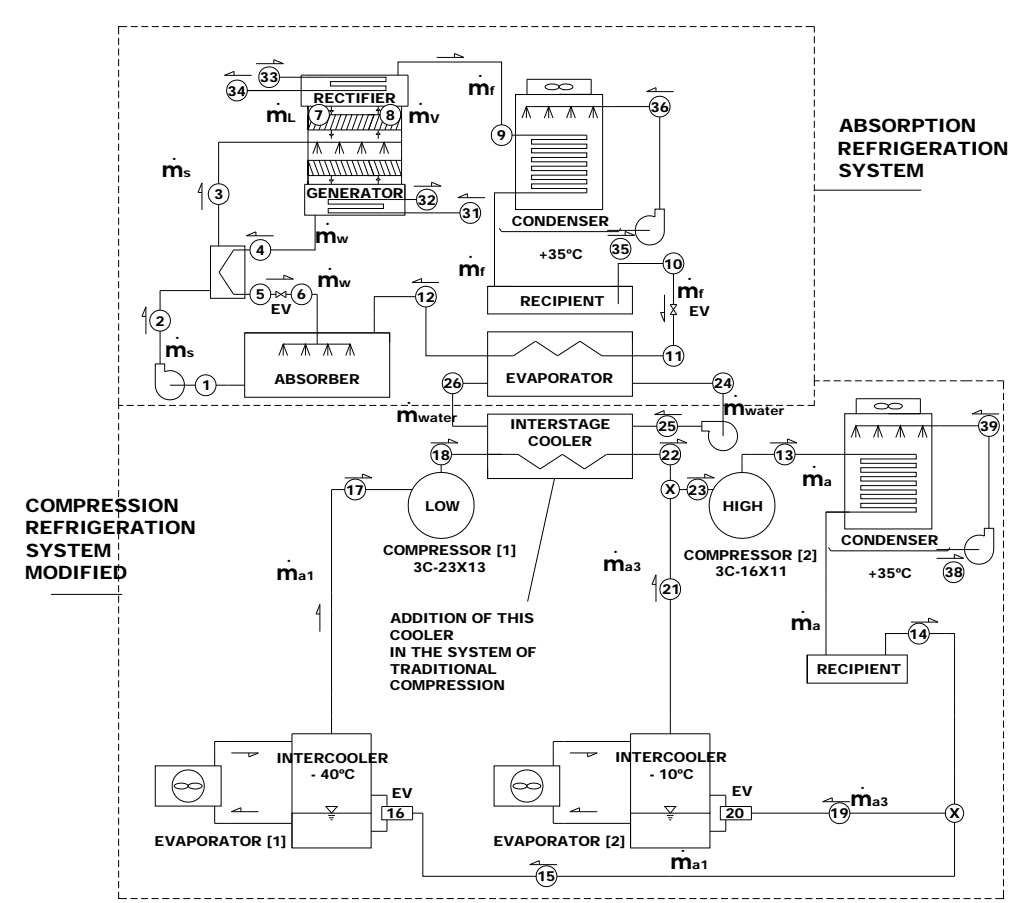

Figure 1. Scheme of Integrated refrigeration System (IRS) (Correa et al., 2008). 
A requirement of thermodynamic evaluation is the result of the energetic and exergetic analysis of the systems involved. Tables 1 and 2 present the parameters considered in the thermoeconomic evaluation of the existing refrigeration system (CRS) and the integrated refrigeration system (IRS), respectively. The exergetic and electric power values provided for engines were obtained previously by Corrêa et al., 2008.

Table 1. Termoeconomics parameters for the CRS.

Useful life cycle of equipments (n) 10 anos

* Annual interest rate (i)

$10 \%$ a.a.

** Maintenance factor $\left(\left(t_{C R S}\right)\right)$

$20 \%$ a.a.

Number of hours per year [h]

$7300 \mathrm{~h}$

Exergy produced of cold $\left(\dot{E}_{f}\right)$

$33.43 \mathrm{~kW}$

Electric powers $\left(\sum \dot{W}_{e}\right)$

$94.18 \mathrm{~kW}$

Electric energy tariff ( $C_{\text {tariff }}$ )

U\$ $0.123 / \mathrm{kWh}$

Source: * BNDES, 2008, ** ABNT, 1994.

Table 2. Termoeconomics parameters for the IRS.

\begin{tabular}{ll}
\hline Useful life cycle of equipments $(\mathrm{n})$ & 10 \\
$*$ Annual interest rate $(i)$ & $10 \%$ a.a. \\
$* *$ Maintenance factor $\left(t_{C R S}\right)$ & $20 \%$ a.a. \\
$* *$ Maintenance factor $\left(t_{A R S}\right)$ & $3 \%$ a.a.
\end{tabular}

Number of hours per year [h] 7300 h/ano

Exergy produced of cold ( $\left.\dot{E}_{f}\right) \quad 44.956 \mathrm{~kW}$

Electric powers $\left(\Sigma \dot{W}_{e}\right)$

Exergy provided to the generator

( $\left.\dot{E}_{G}\right)$

$5.787 \mathrm{~kW}$

Electric energy tariff ( $C_{\text {tariff }}$ ) U\$ $0.123 / \mathrm{kWh}$

Source: * BNDES, 2008, ** ABNT, 1994.

\section{ECONOMIC ANALYSIS OF THE REFRIGERATION SYSTEM}

In obtaining a mean production cost there were applied the considerations made by Bejan, et al.,1996, as follows:

1) total estimative of the investment;

2) economic and financial determination;

3) mean operational cost of the frigorific capacity;

4) investment return at attractiveness taxes.

\section{Total estimate of the investment}

Estimating the total investment in adding ARS it was established a module (Fig.2), widely applied, taking into account the direct and indirect costs.

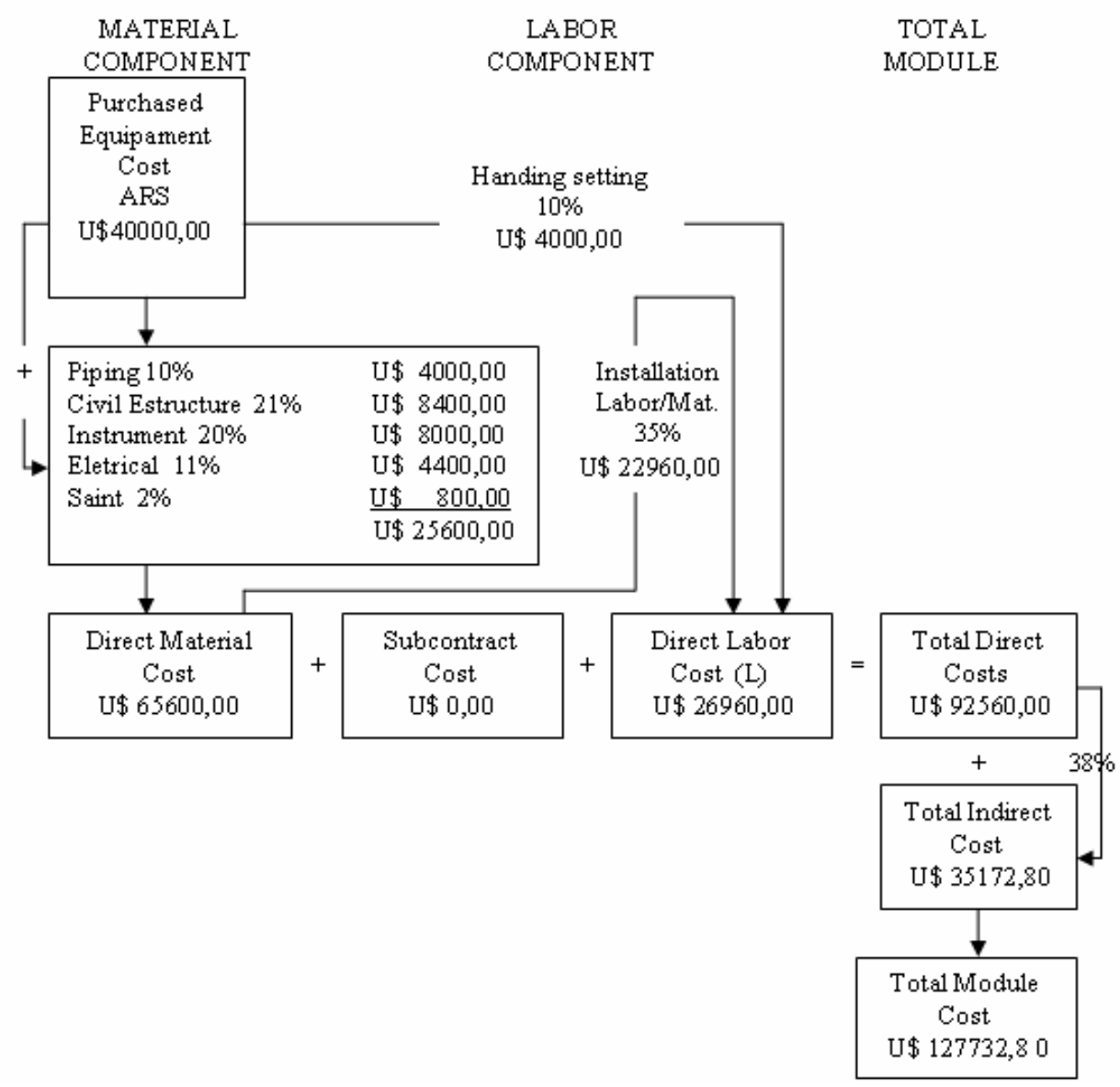

Figure 2. Schematic drawing of IRS. 
In this module, it was applied, by stock, the value of the Absorption ammonia-water equipment with a frigorific capacity of $50 \mathrm{~kW}$, while for the other values it was estimated by percentage representation applied to the components which integrate the total cost. The values of percentage indexes which were applied to each block forming the module, represented, on average, the direct and indirect costs and were based on an estimate method used by Bejan et al., 1996. The direct cost comprises equipment, materials, documentation and direct workforce for execution. While the indirect cost comprises freight, taxes and fees, required for finishing the project.

The total amount invested for adding a refrigeration system by absorption and the intermediary cooler refrigerated by water to compose the IRS reaches U\$ 127732.80.

Economic and financial determination.

When we use an equipment, a number of alternatives come up in which we see the cost of the equipment and their life cycle, the residual values at sale time and the yearly expenses with labour force, energy and maintenance. (Hirschfeld, 1984).

The integrated refrigeration system is made up of a conventional compression system previously applied in the fishing industry, added to the new equipment at an estimated cost according to Fig. 2.

The pre-existing parcel of frigorific equipment of the CRS according to patrimonial balance/2007 has a residual value as it is shown in Table 3.

Table 3. Immobilized active (R\$1,785 = U\$1,00 cotação em 26/01/07).

\begin{tabular}{lllll}
\hline Conta & Cost U\$ & Depreciating goods U\$ & Residual value U\$ & Annual tax \% \\
Frigorific Equipments & 119195.90 & 99195.08 & 20000.82 & 10 \\
\hline Source
\end{tabular}

Source: Jornal Agora /2007- Brasil

Depreciating goods of the Immobilized active corresponds to decreasing the value of this equipment, resulting in the wear and tear by use. This loss of value of actives is registered periodically in the cost or expenditure accounts (depreciation expenses of the period studied), and they have, on the other hand, accounts of register of accumulated depreciation, classified as rectifying accounts of the permanent active. All the accounts of the immobilized presented on the balance sheet were deducted by depreciation calculated at rates which take into account the estimated life cycle of the goods and approved by the Revenue Legislation.

At verifying the convenience of applying IRS there are the following important considerations (Hirschfeld, 1984):
1. the working life considered for analysis will have the remaining life cycle useful duration of the existing equipment (10 years);

2. past input shall not be considered

3. in both systems they will be considered the residual values of resale.

The maximum yearly depreciation tax accepted by the Federal Revenue for equipment and machines is of $10 \%$ per year. In the case of IRS it will be considered the depreciation of existing equipment (CRS) obtained in Table 3, added of depreciation of new equipment (ARS) obtained by the depreciation method by constant percentage. Table 4 presents a scale with depreciating time of ARS, estimated in Fig 2.

Table 4. Depreciated value.

\begin{tabular}{cccc}
\hline Year & Depreciation & \% real & $\begin{array}{c}\text { depreciated value } \\
\text { (U\$) }\end{array}$ \\
0 & & & 127732.80 \\
1 & 12773.28 & $10.00 \%$ & 114959.52 \\
2 & 11495.95 & $9.00 \%$ & 103463.57 \\
3 & 10346.36 & $8.10 \%$ & 93117.21 \\
4 & 9311.72 & $7.29 \%$ & 83805.49 \\
5 & 8380.55 & $6.56 \%$ & 75424.94 \\
6 & 7542.49 & $5.90 \%$ & 67882.45 \\
7 & 6788.24 & $5.31 \%$ & 61094.20 \\
8 & 6109.42 & $4.78 \%$ & 54984.78 \\
9 & 5498.48 & $4.30 \%$ & 49486.30 \\
10 & 4948.63 & $3.87 \%$ & 44537.67 \\
\hline
\end{tabular}

It must be noted that the residual investment amount of $I_{I R S}$ is the sum of depreciated value of the CRS and the ARS, that is U\$ $20000.82+\mathrm{U} \$ 44$

$537.67=$ U\$ 64538.49 


\section{Determining the average operational cost for frigorific production}

Economic criteria were studied in order to permit a changing alternative from the conventional system for the integrated refrigeration system. The analysis was carried out comparing the systems and applying the parameters of Tables 1 and 2, obtaining then, an exergetic cost of frigorific production, where the cash flow (ins and outs in [U\$/kWh]) is divided in parts:

1) For the conventional refrigeration system the cost balance sheet is:

$$
C_{C R S}=C_{i}+C_{e l} \quad[\mathrm{U} \$ / \mathrm{kWh}]
$$

where the mean cost of production of cold in the refrigeration system by compression ( $C_{C R S}$ ) equals the sum of maintenance cost of the investment $\left(C_{i}\right)$ and the cost of energetic input electricity $\left(C_{e l}\right)$.

2) For the integrated refrigeration system the cost balance is:

$$
C_{I R S}=C_{i}+C_{q}+C_{e l} \quad[\mathrm{U} \$ / \mathrm{kWh}]
$$

where the average production cost of cold in the integrated refrigeration system ( $C_{I R S}$ ) equals the maintenance and investment cost $\left(C_{i}\right)$ added to the cost of energetic input in providing heat to the generator $\left(C_{q}\right)$, and the cost of energetic input electricity $\left(C_{e l}\right)$.

The costs are evaluated, using the exergy $(\dot{E})$ as a rational basis for the estimate of costs, giving the thermodynamic values of heat, work and other interactions among a system and its surroundings.

The maintenance cost of investment is calculated by the following expression:

$$
C_{i}=\frac{I \cdot f \cdot t}{H \cdot E_{f}} \quad[\mathrm{U} \$ / \mathrm{kWh}]
$$

Where, $I$ is the value of investment, $t$ is the yearly maintenance factor and $H$ is the number of hours per year of operation.

The recovering factor of capital " $\rho$ " is defined as:

Table 5. Cost of vapor production.

\begin{tabular}{ccccc}
\hline Exergy generator & Latent heat & Mass flow & Cost & Cost/ $\dot{E}_{f}\left(C_{b}\right)$ \\
$\dot{E}_{G}[\mathrm{~kW}]$ & $\Delta h[\mathrm{~kJ} / \mathrm{kg}]$ & $\dot{m}[\mathrm{~kg} / \mathrm{h}]$ & {$[\mathrm{U} \$ / \mathrm{h}]$} & {$[\mathrm{U} \$ / \mathrm{kWh}]$} \\
5.787 & 2383 & 8.742426 & 0.19583 & 0.004356 \\
\hline
\end{tabular}

They will be assigned values of $C_{b}$ in the interval between U\$ 0.0/kWh and U\$ $0.11 / \mathrm{kWh}$ for the water vapor cost. The value zero is attributed when vapor is considered an energetic waste, that is, the present situation, where all the cost of vapor is taken into account for the industry of fish flour. The value of U\$ $0.11 / \mathrm{kWh}$ poses as a wide hypothesis if applying another thermal source of higher value.

The cost of energetic input electricity is

$$
f=\left[\frac{(1+i)^{n} i}{(1+i)^{n}-1}\right] \quad \text { [1/ano] }
$$

where $n$ is the number of years of life cycle of the equipment, and $i$ is the yearly tax of interest rate.

The factor of maintenance, $t$, which appears on eq. (3), takes into account the state of the equipment for duration lower than the Working Life. For the analysis of CRS, the evaluation will be carried out as if the equipment were purchased today by the residual value of resale, remaining the same as for other input in the equipment previously there.

For CRS it was considered yearly $t_{C R S}=20 \%$ over its residual value. For IRS, two factors of maintenances were considered, one concerning the parcel of residual value of CRS of yearly $t_{C R S}=20 \%$ over its residual value and another factor concerning ARS, which was considered $t_{A R S}=3 \%$ yearly over its residual value, as it had less wear for the part of this equipment.

The cost of energetic input in providing heat to the generator is given by

$$
C_{q}=\frac{C_{b} \cdot \dot{E}_{G}}{\dot{E}_{f}} \quad[\mathrm{U} \$ / \mathrm{kWh}]
$$

Where $\dot{E}_{G}$ is the exergy provided to the generator, $\dot{E}_{f}$ is the cold production exergy, and $C_{b}$ is the cost of water vapor per $\mathrm{kWh}$ of the exergy provided by the generator.

The cost per ton of saturated water vapor obtained per hour of boiler which applies BPF oil as fuel, including water treatment is, on average, U\$ 22.40 assuming as basis, the industry in the city of Rio Grande. In an operation at $1200 \mathrm{kPa}$ the cost of vapor used by $\dot{E}_{f}$ (IRS) is presented in table 5 . calculated by

$$
C_{e l}=\frac{\left(\sum \dot{W}_{e}\right) C_{\text {tarifa }}}{\dot{E}_{f}}[\mathrm{U} \$ / \mathrm{kWh}]
$$

where $\left(\Sigma \dot{W}_{e}\right)$ represents the sum of electric powers of engines in the integrated refrigeration system (IRS), where it is the sum of the engines potency used in both systems (absorption-compression).

The mean cost in 2006 of the electricity 
( $C_{\text {tariff }}$ ) to the fishing industry was U\$ 0.123 per kWh, according to the electricity company CEEE Companhia Estadual de Energia Elétrica - RS Brazil.

The cold production exergy, $\dot{E}_{f}$, of the IRS is increased in the proportion of the adding mass flow saved due to intermediary refrigeration carried out by cold water, with a further increase in efficacy and reduction of operating costs.

Return on investment and attractiveness rates

The time for payback investment is the amount of time necessary for benefits, B, coming from an investment which could cover its costs, C, considering an appropriate interest rate, that is, when $\mathrm{C}-\mathrm{B}=0$. For better understanding, we will apply a graphic representation which enables us to see the economic positions through the years, called Cash Flow.

Assuming a cash flow where Benefit or Revenue is the economy of Cost of exergy produced from cold during the return period, n', where the economy is the difference between the cost of exergy produced of cold for CRS and IRS. Fig. 3 is the graphic representation of cash flow to obtain a payback time.

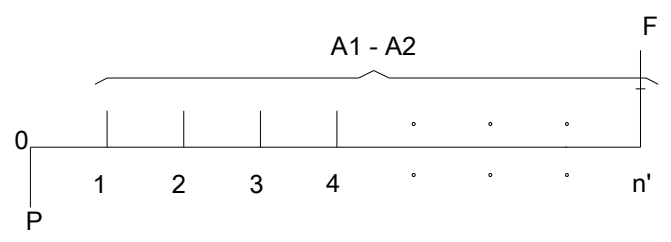

Figure 3. Cash flow to obtain payback time.

Where A1 and A2 represent the average operational cost for CRS and IRS, respectively. flow:

Conventions adopted in the diagram of Cash

1. the horizontal axis represents the time starting from a time considered initial until an instant considered end of the term in question.

2. the positive segments, that is, of horizontal axis upwards, represent: the economy (A1-A2) and the residual value $(F)$ of ARS.

3. the negative segment, that is, of horizontal axis downwards, represents the value of investment (P) of ARS.

Analyzing by the Method of payback investment (Hirschfeld, 1984), in terms of present liquid value (VPL) and evaluating the value for instant $n^{\prime}$, in which VPL is equal to zero, satisfying the eq. (7). The value found four $n$ ' represents the period for returning of investment (pay-back).

$$
V P L=-P+(A 1-A 2)\left(f^{-1}\right)+(F)(g)
$$

Where factor $f^{-1}$ is called present value of a uniform series of payments

$$
f^{-1}=\frac{(1+i)^{n^{\prime}}-1}{i(1+i)^{n^{\prime}}}
$$

And $g$ is the updating factor of value in a simple payment

$$
g=\frac{1}{(1+i)^{n^{\prime}}}
$$

The value of $n^{\prime}$ is calculated iteratively, so that eq. (7) is satisfied. If $n^{\prime}$ (payback for investiment) is lower than $n$ (life cycle of the goods invested), the goods must be purchased. The amount of investment necessary is U\$ 127732.80 and the economic condition of the company takes into account that a payback of 10 years can be considered adequate to the function of productive process involved.

\section{RESULTS AND DISCUSSION}

The results of balance of cost for CRS, regarded with frigorific production, applying Eqs. (1,3 and 6) are presented in Table 6.

Table 6. Cost results for the CRS.

\begin{tabular}{ccc}
$C_{i}[\mathrm{U} \$ / \mathrm{kWh}]$ & $C_{e l}[\mathrm{U} \$ / \mathrm{kWh}]$ & $C_{C R S}[\mathrm{U} \$ / \mathrm{kWh}]$ \\
0,002668 & 0,346519 & 0,349187 \\
\hline
\end{tabular}

The results of balance of cost for IRS, related to the frigorific production applying Eqs. (2, 3, 5 and 6) are presented in Table 7 for $0 \leq C_{b} \leq 0,11$ where $C_{i}$ and $C_{e l}$ are constants with respective values U\$ 0,002646/kWh and U\$ 0,257677/kWh.

Table 7 - Cost results for the IRS.

\begin{tabular}{ccc}
$C_{b}[\mathrm{U} \$ / \mathrm{kWh}]$ & $C_{q}[\mathrm{U} \$ / \mathrm{kWh}]$ & $C_{I R S}[\mathrm{U} \$ / \mathrm{kWh}]$ \\
0 & 0 & 0,260323 \\
0,01 & 0,0012873 & 0,26161 \\
0,02 & 0,0025745 & 0,262898 \\
0,03 & 0,0038618 & 0,264185 \\
0,04 & 0,005149 & 0,265472 \\
0,05 & 0,0064363 & 0,266759 \\
0,06 & 0,0077236 & 0,268047 \\
0,07 & 0,0090108 & 0,269334 \\
0,08 & 0,0102981 & 0,270621 \\
0,09 & 0,0115853 & 0,271908 \\
0,10 & 0,0128726 & 0,273196 \\
0,11 & 0,0141598 & 0,274483 \\
\hline
\end{tabular}




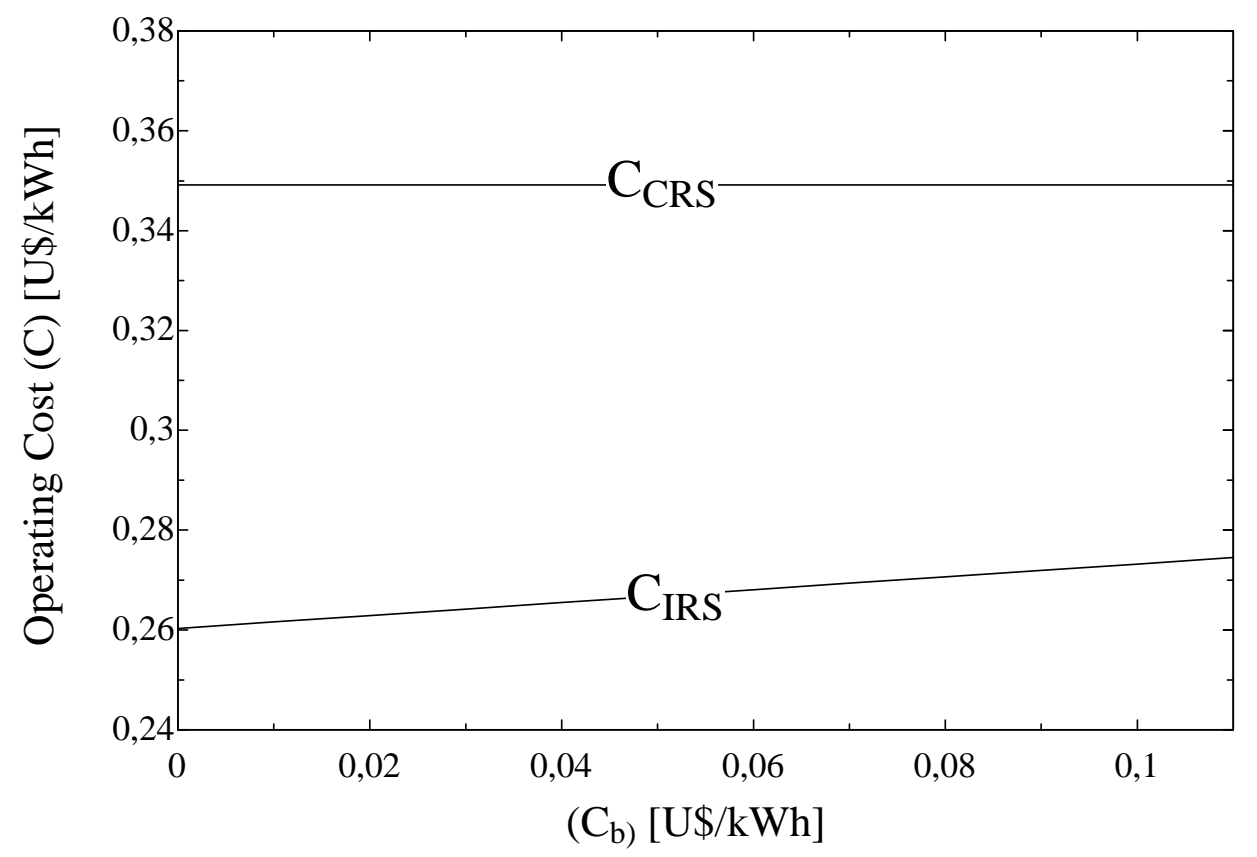

Figure 4. Operational Cost of CRS and of IRS in terms of $C_{b}$.

It is possible to observe that the average cost of CRS is constant and it is worth 0.349187 [U\$/kWh] obtained by eq. (1), and as expected, the average cost of IRS rises as the corresponding term to the cost of calorific energy output (Cq).

For a frigorific production of $33.43 \mathrm{~kW}$, according to Table 7 for CRS, the annual average cost obtained is of U\$ $0.349187 / \mathrm{h}$ for each $\mathrm{kW}$ of frigorific production. Considering 7300 hours of operation (corresponding to $83.3 \%$ of the number of hours in a year), the value of annual average cost of CRS is presented on table 8 .

Table 8. Average annual operating cost for the CRS.

\begin{tabular}{cccc}
$C_{C R S}$ & $H$ & $\dot{E}_{f}$ & Average cost \\
{$[\mathrm{U} \$ / \mathrm{kWh}]$} & (horas) & {$[\mathrm{kW}]$} & A1 [U\$] \\
0,349187 & $7300 \mathrm{~h}$ & 33,43 & $85215,25 *$ \\
\hline
\end{tabular}

*Value of A1 of cash flow presented in Figure 3

The yearly average operating cost of cold production, according to Table 7 for the IRS, varies according to the cost of the input of calorific energy, ranging from U\$ $0.26 / \mathrm{kWh}$ to U\$ $0.274 / \mathrm{kWh}$, according to the values assigned to $C_{b}$ which are in the interval of U\$ 0.00 to U\$ 0.11 . These values calculated of the average cost were based in a frigorific production of $44.956 \mathrm{~kW}$ obtained with the integration of the subsystem of absorption, operating in the same $7300 \mathrm{~h}$. It is understood than the IRS must operate at a lower number of hours a year to produce the same frigorific production carried out by the CRS (of $33.43 \mathrm{~kW}$ ). The number of hours necessary for operation of the IRS corresponds to 5428 hours (25.64 \% lower than CRS), obtained by the criterion of proportionality between the frigorific productions between the two systems. Hence, for a year of 5428 hours of operation with a frigorific power of $44.956 \mathrm{~kW}$, and applying the same methodology to obtain the yearly average cost A1 of Table 8 , we obtain in Table 9 the variation of production of cold A2 (U\$/year).

Table 9. Average annual operating cost of the IRS.

\begin{tabular}{ccc}
$C b$ & $C_{I R S}[\mathrm{U} \$ / \mathrm{kWh}]$ & Average cost A2 [U\$] \\
0 & 0,260323 & 63524,32 \\
0,01 & 0,26161 & 63838,44 \\
0,02 & 0,262898 & 64152,56 \\
0,03 & 0,264185 & 64466,68 \\
0,04 & 0,265472 & 65780,8 \\
0,05 & 0,266759 & $65409,09,03$ \\
0,06 & 0,268047 & 65723,15 \\
0,07 & 0,269334 & 66037,27 \\
0,08 & 0,270621 & 66351,39 \\
0,09 & 0,271908 & 66665,51 \\
0,1 & 0,273196 & 66979,62 \\
0,11 & 0,274483 & \\
\hline
\end{tabular}

*Value of A2 of cash flow presented in Fig. 3

The difference A1-A2 when positive corresponds to the operational economy in applying IRS rather than CRS.

The parameters considered in the calculation of payback investment concerning to the liquid present value, applied to eq. (7) of the thermoeconomic analysis of IRS are presented in Table 10. In calculating the lowest payback time it was applied the average cost A2 of U\$ 63524.32, 
condition where $C_{b}=0$, due to its use in the integrated system of a parcel of thermal energy wasted in making fish flour, present in the frigorific fishing industry.

Table 10. Payback time used parameters.

\begin{tabular}{ll} 
Present value (P) & U\$ 127732.80 \\
Residual value (F) & Tabela 3 \\
Low interest rate (i) & $10 \% a$ \\
Average cost A1 [U\$] of the IRS & U\$ 85215,25 \\
Average cost A2 [U\$] of the IRS & U\$ 63524,32 \\
\hline
\end{tabular}

Applying Eq. (7), where for the $1^{\mathrm{a}}$. Estimative for $n^{\prime}=10$ (life cycle of the equipment) has: $f^{-1}=6.145, g=0.3855$ and the residual value of $\mathrm{F}$ = U\$ 44537.67 are the values of depreciated equipment for 10 years (table 4 ). The present liquid value VPL = U\$ 22727.24 is calculated with eq. (7). The positive result shows the viability of the investment. We shall, then, estimate a lower number of years, so that the Present Liquid Value is equal to zero, to determine the payback time of the investment.

In the second estimate, for $n^{\prime}=5$ we have: $f^{-1}=3.791, g=0.6209$ and the residual value of $\mathrm{F}=\mathrm{U} \$ 75424.94$ (value of the equipment depreciated for 5 years). The present liquid value shows a positive result, $\mathrm{VPL}=\mathrm{U} \$ 1328.86$ approaching zero, points out that the number of years for a payback is lower than 5 years.

In the $3^{\text {rd }}$ estimative, $n^{\prime}=4$ we have: $f^{-1}=3$. 170 and $g=0.6830$ and the residual value of $F=$ U\$ 83805.49 depreciated for 4 years, present $\mathrm{VPL}=-\mathrm{U} \$ 1$ 733.40. The negative value points out that the payback time for the investment is higher than 4 years. Interpolling 4 and 5 years, so that $\mathrm{VPL}=0$ we have a payback time $n^{\prime}=4.56$ years .

It means that the Costs of investments at $10 \%$ a.a. with the residual value given, will be paid off after 4.56 years of use, which is lower than 10 years of life cycle of the equipment. This payback time of 4.56 years was obtained for a fuel cost $\left(C_{b}\right)$ of U\$ $0.00 / \mathrm{kWh}$.

We can note by Table 9 that the average operational cost A2 has a close connection with the cost of fuel. Hence, the higher the fuel price, the longer the payback time of the investment. Fig.5 presents the Sensitivity Curve of Payback time of investment, considering the variation of price of the fuel.

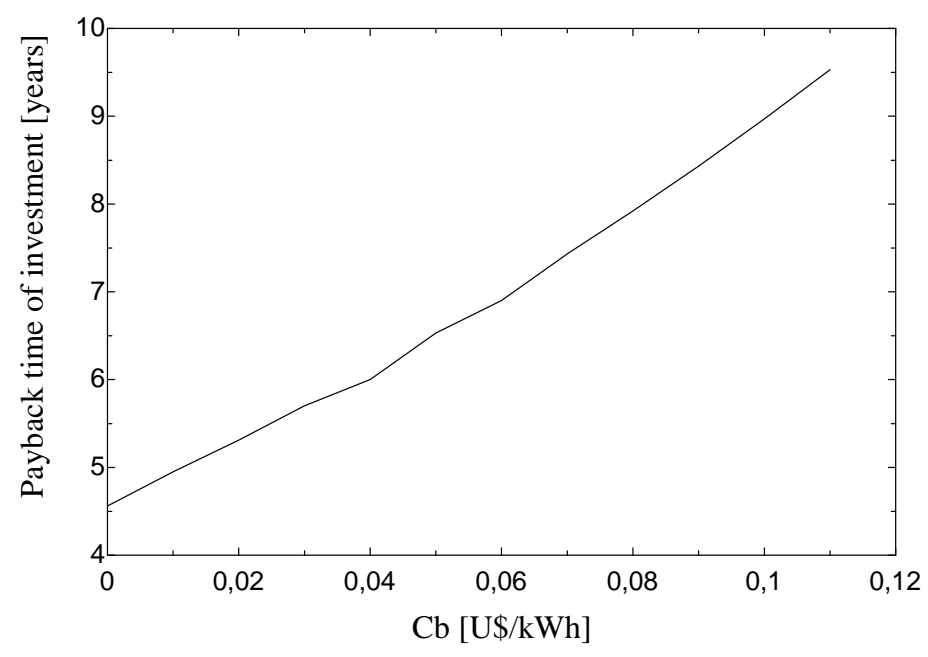

Figure 5. Curve of sensibility of payback time of investment.

We can also observe that the economic viability of installing IRS favors a beneficial situation even under they hypothesis of altering the price of the fuel.

\section{CONCLUSION}

Applying the Integrated System Refrigeration (IRS), when compared to the compression system (CRS), proved that IRS is able to produce the same "amount of cold" with a lower estimated cost, that is, with more efficiency. The higher performance of this process combined with the use of electric energy is due to:

a) not applying liquid cooler of the condensator to carry out intermediate refrigerating within the stages, but for a refrigerating heat changer for water, and sustained by the absorption system (ARS). Thus, every working fluid applied in stalling is used in production of cold. b) using the thermical parcel refused during the work of the ARS generator. Beforehand, this parcel was analyzed at zero cost. However, they were also considered values for a cost of fuel at $U \$ 0.00<C_{b}<U \$ 0.11$ per $\mathrm{kWh}$, even then, with 
viability of the integrated system, by presenting a payback time of investment lower than 10 years (estimated time of life cycle of the equipment). Hence, an important criterion so that it can be launched is the selection of a company which has a proven parcel of heat unused in the productive process.

The results obtained by comparing the tow refrigeration systems pointed out the viability of the integrated refrigeration system, with an operational yearly time of up to $25.64 \%$ shorter than the existing refrigerating system, due to this same increase of exergy of frigorific production $\dot{E}_{f}$, which allowed a payback time of investment of 4.6 years, for a cost of fuel $C_{b}=0$. The sensitive reduction of Operational Costs, along with an increase of Frigorific Capacity provided by integration the compression-absorption systems, brings out more competitiveness of prices in the market of frigorific products.

\section{REFERENCES}

ABNT, 1994. Rio de Janeiro. NBR5462, Confiabilidade e mantenabilidade - terminologia. Rio de Janeiro, 37p.

ASHRAE Handbook. 1994, System Practices for Ammonia Refrigerant. ASHRAE Refrigeration System and Applications, Atlanta, Ga.

Bejan, A., Tsatsaronis, G., and Moran, M., 1996, Thermal design and optimization, Wiley, New York.

BNDES, Banco do Desenvolvimento de Todos os Brasileiros, 2008. http:/ www.bndes.gov.br/linhas/finame.asp. Acessed in august 2008.

Erlach, B., Serra, L., and Valero, A.,1999. Structural theory as standard for thermoeconomics. Energy Conversion and Management, Vol 40, 1627 $-1649$.

Corrêa, G. A., Souza, J. A., PrénticeHernandes, C., and Rocha, L. A. O., 2008. Energy and exergy thermodynamic analysis of a two-stage compression refrigeration system integrated with an absorption system $\left(\mathrm{NH}_{3}+\mathrm{H}_{2} \mathrm{O}\right)$, Engenharia Térmica (Thermal Engineering), Vol.7 No1, p 10 - 20.

Hirschfeld, H., 1984, Engenharia econômica. 3. ed., Atlas, São Paulo.

Misraa, R. D., Sahoob, P. K., and Gupta, A., 2006, Thermoeconomic evaluation and optimization of an aqua-ammonia vapourabsorption refrigeration system. International Journal of Refrigeration, 29, pp. 47 - 59.

Pellegrini, L. F., Costa, R. P., and Oliveira, S., 2005. A atribuição de custos em sistemas energéticos: A termoeconomia como base de cálculo. XXV Encontro Nacional de Engenharia de Produção ANEGEP. Porto Alegre, RS.

Stoecker, W. F., 1998, Industrial refrigeration handbook. McGraw-Hill, New York.
Souza, M. R., Menezes, J. O., Martins, J. W. M., Jesus, M. F., Carnelossi, M. A. G., and Silva, F. G., 2004, Análise técnica e econômica da unidade piloto de refrigeração no armazenamento de cebolas. Revista Brasileira de Produtos Agroindustriais, Campina Grande, v.6. n 2. 165 170. ISSN 1517-8595. 